\title{
AGRICULTURAL POLICY REVIEW PART 1: GROSS REVENUE INSURANCE PLAN
}

\section{FRED THORNTON, JOCE BOWMAN, and DAVID STRUTHERS, Western}

Resource Management Associates Limited, Box 4-B Site 2, Yorkton, Saskatchewan. S3N 2V4

The economic viability of prairie farm operations has declined significantly over the past decade. In the early 1980 s, farmers received the majority of their net income from the marketplace. Since 1985, however, marketplace revenues have declined and government programs have been implemented to support realized net farm income. This assistance has been provided by ongoing programs, such as crop insurance, and by ad hoc programs such as the Special Canadian Grains Program, the Canadian Crop Drought Assistance Program, and the CanadaSaskatchewan Crop Assistance Program. $^{2}$

Current programs (ongoing and ad hoc) have run into deficit positions. These programs were not designed to handle the present situation which has come about as a result of international grain subsidies and declining farm gate prices. Spokespersons for the government, the agriculture industry, and producer groups have stressed the need for new farm safety net programs that meet the following criteria:

\section{- predictability;}

- cost-sharing by governments and producers; and

resource neutrality.

As part of the ongoing process of agriculture policy review, a Grains and Oilseeds Safety Net Committee was established to design new income support programs that would meet the criteria above. The objective was to develop a safety net program that would smooth out fluctuations in net revenue arising from production and marketing risks beyond the farmer's control. The committee included representatives from the major producer groups (Western Canadian Wheat Growers, Canadian Wheat Board Advisory Committee, Canola Growers Association, National Farmers Union, United Grain Growers, Saskatchewan Wheat Pool), as well as representatives from the federal and provincial governments. The Safety Net Committee recommended two programs, the Gross Revenue Insurance Plan (GRIP) and the Net Income Stabilization Account (NISA). The more significant of these two is GRIP, a comprehensive insurance program that provides: production (crop yield) insurance and revenue (price) insurance.

The production insurance component has been available to Saskatchewan producers through the Saskatchewan Crop Insurance Corporation (SCIC) for over 30 years. Insurance is provided on the basis of long-term average crop yields, using either area-based or individual yield records. Under the area coverage option, coverage levels are based on 
15 year moving average yields that SCIC has calculated for summerfallow and stubble cropping in each of 23 "risk" areas in the province. Higher coverage is offered for crops seeded on summerfallow than for crops on stubble. Under the individual coverage option, a producer's insurable yield level for each crop is determined by averaging 10 years of his/her individual yield records. In the event that a producer does not have 10 years of personal records, he/she must rely, in part, on the 15 year moving average yields for his/her "risk" area (area coverage). For example, a producer with 2 years of individual records would have to use 8 years of area records to calculate his/her 10 year yield averages. Each year the producer would use more of their own data, until such time as they had 10 years of personal records. Production insurance payments are triggered when uncontrollable natural hazards, such as drought, reduce crop yields below guaranteed levels.

The revenue insurance component was introduced as GRIP in 1991. Farmers used their individual 10 year crop yield records (their yield guarantees under production insurance) and a 15 year moving average price, indexed to the cost of farm inputs, to calculate a gross revenue insurance level per acre. As in the case of production insurance, producers with less than 10 years of personal yield records used yield data for their risk area to calculate coverage levels. The program was based on individual crop commodities (i.e., each crop was insured individually). Payments were triggered when the revenue received from the marketplace and from production insurance was below the insured revenue level. With the introduction of GRIP in 1991, farmers could choose between three program options: production insurance only, revenue insurance only, or a combined program that insured crop yield as well as gross revenue.

From an agro-economic perspective, the 1991 version of GRIP was criticized for two reasons: 1

1) Market responsiveness - Ideally, farmers should make their annual planting decisions based on market signals. The mix of crops and livestock they decide to produce should be determined by market opportunities and the degree of risk they are willing to accept. Under the 1991 GRIP program, revenue insurance levels were crop-specific. This distorted cropping decisions by providing a direct incentive to produce those crops with the highest revenue guarantees, even if market demand was low or the producer had no prior experience growing the crop. This, combined with the fact that the program did not include forages, reduced incentives for crop diversification.

2) Moral hazard - Moral hazard occurs when a program or policy takes away the incentive to do the best job possible with a given set of resources. Under the 1991 GRIP program, guaranteed revenue levels were higher than the expected market revenues for all crops. With expected prices so low that there was little probability that market revenues could exceed the GRIP guarantee, producers had no incentive to grow a good crop. Instead, producers could choose to accept the guarantee and maximize income by minimizing expenditures for cropping inputs such as pedigreed seed, fertilizer, and pesticides.

To rectify these problems, the Saskatchewan government changed the GRIP program for 1992. Under the 
new program, production and revenue insurance remain as separate entities. Production insurance reverts to an annual program and producers can choose to insure some or all of their crops. The revenue insurance component operates like a deficiency payment. Benefits are determined from: producers' 10 year average yields; their SCIC risk area; crop(s) seeded; whether the crop is grown on summerfallow, stubble, or irrigated lands; and soil quality. Payouts and premiums are determined for a "basket of crop commodities" grown in a given risk area. Producers receive a regionally based acreage payment indexed to their individual 10 year yield information. Payouts are based on the number of seeded acres, regardless of the mix of crops that is grown. This approach is more market responsive since payments are not based on individual crops. Producers will tend to grow crops that will earn the highest market revenue. The risk of moral hazard is also reduced, since the annual payout is received for each crop grown, regardless of crop yields and market revenue. Producers will attempt to optimize crop yields through the use of inputs, since higher yields will result in higher economic returns.

\section{Potential impacts on the land-} scape Despite the fact that the agricultural policy review process identified resource neutrality and environmental sustainability as key components of the framework for new programs and policies, the 1992 version of the Gross Revenue Insurance Plan has several flaws:

1) Land use - Currently, GRIP does not provide adequate disincentives to prevent undesirable changes in land use. Like many other programs, GRIP is acreage based. The payouts that producers receive are based on seeded acreage. The more seeded acreage a producer has, the more program benefits they will receive. In order to maximize program benefits, producers have two options:

a) They can increase the proportion of their cultivated acreage that is seeded by reducing the amount of summerfallow acres. This has positive implications in terms of soil conservation. Summerfallow tillage increases the potential for soil erosion losses and reduces the longterm productivity of the soil. However, producers with less than 10 years of personal yield records, who must use risk area data to calculate their long-term yield coverage levels, maý have lower coverage if they decide to continuous crop, since the risk area data provides lower yield guarantees for stubble than for summerfallow.

b) They can expand their seeded acreage by converting tame forage, native grassland, wetlands, and wooded areas to cultivation. Under the revenue insurance component of the GRIP program, an annual seeded acreage cap is calculated for each producer. In any year, seeded acreage above this cap is not eligible for revenue insurance coverage. This acreage cap was designed to limit increases in seeded acreage above those normally occurring as a result of yearly fluctuations in weather, markets, etc. However, the cap does not prevent producers from continuing to expand their cultivated acreage base. Since the cap is based on the ratio between seeded and cultivated acres, producers can continue to gradually convert more land to cultivation without affecting their seeded acreage cap. As long as they maintain this ratio (or increase it), their entire seeded acreage in any given year will be eligible for revenue insur- 
ance coverage. The production insurance component of GRIP also facilitates these types of activities by providing yield coverage for fragile soils that are not suited to annual crop production. Canada Land Inventory (CLI) class 5 (improvable pasture) and class 6 (non-improvable pasture) qualify for production insurance the year that they are converted to crop land. The removal of natural vegetation and wetlands, along with the subsequent cultivation of these fragile soils, increases the potential for soil degradation and results in losses of wildlife habitat. These practices will also have serious negative implications for the functioning of the ecological processes that are vital to the sustainability of the prairie landscape.

2) Diversification - Diversification is a critical component of an economically and environmentally sustainable landscape. Diversification may involve longer crop rotations incorporating a broader range of crops, conservation tillage practices, andior a better balance of cropping and livestock enterprises. Insurance programs tend to promote specialization over diversification by reducing the risk associated with investing all of one's resources into a single type of venture. In the case of agriculture, this has resulted in the misuse of land and other natural resources. Land that is best suited for livestock production and/or wildlife habitat has been converted to annual crop production. The GRIP program does not promote diversification. Forages, forage seed, tame pasture, and rangeland are not eligible for revenue insurance coverage. The exclusion of these crops results in an economic disincentive to integrate crop and livestock production and, in particular, to grow forages which provide good protection against soil degradation.
3) Soil conservation - There are two separate issues relating to the effects that GRIP may have on soil conservation:

a) Under area coverage, production insurance penalizes producers who adopt soil conserving practices such as extended crop rotations and/or conservation tillage by differentiating between stubble and summerfallow yield coverage levels. Higher coverage is offered on summerfallow crops than for crops on stubble. Also, if conservation practices result in lower yields over the short-term, producers will be faced with lower coverage levels and increased premiums.

b) By introducing a new set of incentives and disincentives, the GRIP program may influence land management decisions. Since the program is based on seeded acreage, producers may be reluctant to employ soil conservation practices that will take land out of production (eg. forage establishment, shelterbelts, etc.) even if it is the obvious best use of the land. In this respect, GRIP is in direct contradiction with government funded soil conservation and wildlife habitat programs such as the Save Our Soils program and the Permanent Cover Program.

Possible Solutions It is obvious that, despite the government's claim that all policies must be environmentally sound, the developers of the GRIP program did not give thorough consideration to environmental sustainability when they designed the program. The 1992 version offers some improvement in the area of market responsiveness and diversification, but there is still a need for further changes. The following suggestions are provided: 
1) The seeded acreage cap should be revised so that producers can only increase seeded acreage by increasing the proportion of their current cultivated acreage that is seeded annually. Any additional land that is converted from native vegetation to cultivation should not be eligible for revenue or production insurance coverage.

2) Modify Crop Insurance policy so that fragile soils (CLI classes 5 and 6) do not qualify for coverage under either the production or revenue insurance components of GRIP. Insurance coverage for these lands could be phased out over a reasonable time frame (5 to 10 years), in conjunction with soil conservation programs such as the Permanent Cover Program and the Save Our Soils program.

3) Develop a method of including forages, forage seed, tame pasture, and rangeland in the program. This change was promised for 1992, but nothing has been done.
4) Reward soil conservation practices by increasing the stubble yield coverage to summerfallow levels under the area coverage option. This will provide farmers who do not have 10 years of personal yield history with an incentive to stubble crop, since they will not be penalized by lower coverage levels.

The Farm Income Protection Act legislation, which enabled GRIP and NISA, requires that an environmental assessment be conducted within two years of the programs inception. This process is currently being co-ordinated by the Bureau of Environmental Sustainability, Policy Branch, Agriculture Canada.

1. GRAY, R., W. WEISENSEL, $K$. ROSAASEN, H. FURTAN, and D. KRAFT. 1991. Proposed amendments to GRIP. Departments of Agricultural Economics, Universities of Saskatchewan and Manito ba. 12 pp.

2. MAKOWSKY, M. 1991. GRIP/NISA. Presented at the Saskatchewan Institute of Agrologists' 46th Annual Convention. April 11, 1991. Regina, Saskatchewan. 12 pp.

The Wisconsin nesting [of Passenger Pigeons in 1871] was the largest ever described, and its awesome dimensions have been at seventy-five to ten by fifteen miles, an area of no less that seven hundred and fifty square miles. Assuming a minimum average of twenty-five trees per acre and five pairs per tree, this single nesting was shared by $136,000,000$ birds ... little more than one twentieth the size of the flight described by Wilson [in 1810].... The last wild pigeon in Wisconsin was taken in 1899... - Peter Matthiessen. 1959. Wildlife in America. Viking, NY. (Pp.159-160) 